\title{
Association of Neutrophil-Lymphocyte Ratio with the Presence and Severity of Degenerative Aortic Valve Stenosis
}

\author{
Dejeneratif Aort Kapak Stenozu Varlığı ve Ciddiyeti ile Nötrofil-Lenfosit Oranı Arasındaki İlişki
}

\author{
Murathan Kucuk ${ }^{1}$, Can Ramazan Oncel ${ }^{2}$, Mustafa Ucar ${ }^{1}$, Fulya Avci Demir ${ }^{1}$, Atakan Yanıkoglu ${ }^{1}$, Aytul Belgi Yildirim ${ }^{1}$ \\ ${ }^{1}$ Akdeniz University Medical Faculty, Department of Cardiology, Antalya, Turkey \\ ${ }^{2}$ Ataturk State Hospital, Department of Cardiology, Antalya, Turkey
}

\section{ABSTRACT}

Objective: In different studies, it has been shown that degenerative aortic stenosis and atherosclerosis had a common pathogenic mechanism. The goal of this study was to examine the association between NLR and the presence and severity of degenerative aortic valve stenosis.

Methods: Echocardiographic data (from May 2011 to September 2013) of our cardiology department was reviewed retrospectively. After evaluation according to exclusion criteria's, a total of 103 patients with degenerative AS and a control group of 35 age- and gender- matched patients who had normal echocardiographic findings were included in the study.

Results: The level of NLR was highest in severe AS. The neutrophillymphocyte ratio was significantly higher in severe AS group than for the mild and moderate AS group $(1.95 \pm 0.42,2.31 \pm 0.69,2.67 \pm 0.73 ; p<0.001$ respectively). In comparison of the degenerative aortic stenosis groups with the control group, NLR in all aortic stenosis groups was found to be significantly higher than the control group $(p<0.001)$. In addition, there was a statistically significant correlation between NLR and transaortic peak pressure gradient in patients with degenerative aortic stenosis ( $r$ : 0.626, $\mathrm{p}<0.001)$.

Conclusion: The NLR, which is an inexpensive and readily available marker of chronic inflammation, may be useful in predicting the presence and severity of degenerative aortic stenosis.

Key Words: Aortic stenosis, inflammation, neutrophils

\section{ÖZET}

Amaç: Farklı çalışmalarda dejeneratif aort darlığı ve aterosklerozun ortak bir patojenik mekanizmaya sahip olduğu gösterilmiştir. Bu çalışmanın amacı, NLR ile dejeneratif aort kapak darlığının varlığı ve ciddiyeti arasındaki ilişkiyi incelemekti.

Gereç ve yöntemler : Kardiyoloji bölümünün ekokardiografik kayıtları ( mayıs 2011 ve eylül 2013 ) retrospektif olarak incelendi. Dışlanma kriterleri değerlendirildikten sonra 103 dejeneratif aort darlığı hastası ile normal ekokardiografik bulguları olan, yaş ve cinsiyet olarak eşleştirilmiş 35 hasta çalışmaya alındı.

Bulgular : NLR seviyesi ciddi aort darlığı (AD) grubunda en yüksek bulundu. Nötrofil lenfosit oranı ciddi $A D$ grubunda hafif ve orta aort darlığı gruplarına

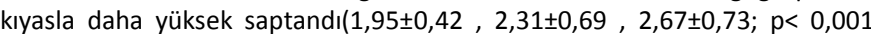
sırasıyla).Tüm aort darlığı gruplarında NLR kontrol grubuna kıyasla yüksek saptandı. $(p<0,001)$. Ayrıca dejeneratif aort darlığı hastalarında transaortik pik basınç gradienti ile NLR arasında istatiksel olarak anlamlı bir korelasyon izlendi ( $r: 0,626, p<0,001)$.

Sonuç: Kronik enflamasyonun ucuz ve kolay ulaşılabilir bir göstergesi olan NLR ; dejeneratif aort darlığının varlığı ve ciddiyetini tahmin etmede kullanışlı bir rol oynayabilir.

Anahtar Sözcükler: Aort darlığı, enflamasyon, nötrofiller

Geliş Tarihi: 06.01.2016

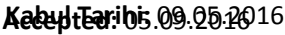

Address for Correspondence / Yazışma Adresi: Can Ramazan Oncel, MD, Ataturk State Hospital, Department of Cardiology, Anafartalar street 07040, Antalya, Turkey E-mail: r_oncel@hotmail.com

(CTelif Hakkı 2016 Gazi Üniversitesi Tıp Fakültesi - Makale metnine http://medicaljournal.gazi.edu.tr/ web adresinden ulaşılabilir.

(C) Copyright 2016 by Gazi University Medical Faculty - Available on-line at web site http://medicaljournal.gazi.edu.tr/

doi:http://dx.doi.org/10.12996/gmj.2016.38 


\section{INTRODUCTION}

Aortic valve stenosis (AS) is most common valvular heart disease in developed countries (1). In different studies, it has been shown that degenerative aortic stenosis and atherosclerosis had a common pathogenic mechanism. Progression of aortic valve stenosis involves an active cellular and inflammatory process which resembles atherosclerosis. Since chronic systemic inflammation plays an important role in the development of atherosclerosis, this process may also play a critical role in the development and progression of degenerative aortic stenosis (2-4). Recently it was shown that the neutrophil-lymphocyte ratio (NLR) is an important marker of inflammation in cardiac disorders, especially in atherosclerotic heart disease $(5,6)$.

The goal of this study is to examine the association between NLR and the presence and severity of degenerative aortic valve stenosis.

\section{MATERIALS and METHODS}

The echocardiographic data (from 2012 and 2013) of our cardiology department was reviewed retrospectively. After evaluation according to exclusion criteria's, a total of 103 patients with degenerative AS and a control group of 35 age- and gender- matched patients, who had normal echocardiographic findings, were included in the study. The exclusion criteria's were significant valvular heart disease (except for degenerative aortic valve disease), heart failure, presence of acute coronary syndrome, previous cardiac surgery, presence of atherosclerotic heart disease, malignancy, renal or hepatic failure, acute or chronic infectious disease, autoimmune disease, anemia (hemoglobin levels lower than $13 \mathrm{~g} / \mathrm{dl}$ in men and $12 \mathrm{~g} / \mathrm{dl}$ in women), pregnancy, recent blood transfusion, hematological disease, acute or chronic pulmonary disease, congenital and rheumatic aortic stenosis. Basal and clinical characteristics, laboratory parameters and the medical history of coronary heart disease were reviewed from the patients' medical files. Venous blood count was obtained from all the patients on admission as a routine part of clinical examination on the same day that the transthoracic echocardiography was performed. Neutrophils, lymphocytes and white blood cells were measured as part of the automated complete blood count. The NLR was calculated as the ratio of the neutrophils and lymphocytes, both obtained from the same automated blood sample. Diabetes mellitus was defined as a fasting blood glucose level $>126 \mathrm{mg} / \mathrm{dl}$ or current use of a diet or medication to lower blood glucose and/or $\mathrm{HbA} 1 \mathrm{c}>6.5 \%$. Hypertension was considered to be present if the systolic pressure was $>140 \mathrm{mmHg}$ and/or diastolic pressure was $>90 \mathrm{mmHg}$ as well as patients receiving antihypertensive treatment were accepted as hypertensive.
Hyperlipidemia was defined as LDL cholesterol $>130 \mathrm{mg} / \mathrm{dl}$, Total cholesterol $>200 \mathrm{mg} / \mathrm{dl}$, Triglyceride $>\mathbf{2 0 0} \mathrm{mg} / \mathrm{dl}$ or current use of any antihyperlipidemic medication.

Transthoracic echocardiography

Echocardiography was performed in the left lateral decubitus position with the GE-Vingmed Vivid 7 system (GE-Vingmed Ultrasound AS, Horten, Norway) ultrasound device. The left ventricle ejection fraction was calculated according to the Teicholtz formula based on the diastolic and systolic diameters of the left ventricle. Mild aortic stenosis was defined by a peak aortic doppler velocity of $2.6-2.9 \mathrm{~m} / \mathrm{sn}$ and peak gradient $<35 \mathrm{mmHg}$, moderate as having a peak doppler velocity of $3.0-4.0 \mathrm{~m} / \mathrm{sn}$ and $35-60 \mathrm{mmHg}$ peak gradient, and severe as having a peak aortic doppler velocity of $>4.0$ $\mathrm{m} / \mathrm{sn}$ and $>60 \mathrm{mmHg}$ peak gradient.

\section{Statistical analysis}

Continuous variables are presented as mean \pm standard deviation, while categorical variables are given as percentages. The Kolmogorov-Smirnov test was used to verify the normality of the distribution of continuous variables. Statistical analysis of clinical data between the two groups consisted of unpaired $t$-tests for parametric data and Mann Whitney $U$ test analysis for nonparametric data, whereas one-way analysis of variance or Kruskal-Wallis tests was used to evaluate comparisons between the four groups. Post-hoc analysis was carried out by Bonferroni correction test and Fisher's least significant difference (LSD). Correlations were assessed with the Spearman correlation coefficient and the chi-square/Fisher's exact test were used for categorical variables. Analyses were performed with PASW 18 (SPSS/IBM, Chicago, IL, USA) software and two-tailed P-value less than 0.05 was considered statistically significant.

\section{RESULTS}

A total of 103 patients with degenerative aortic stenosis and 35 patients in a control group were included in the study. The demographical, echocardiographical and hematological characteristic findings of the study group are presented in Table 1. There were no differences between the ages and genders of the patients within the groups. Also the distribution of HT, DM, and HPL was similar in all four groups. The level of NLR was highest in severe AS. The neutrophil-lymphocyte ratio was significantly higher in the severe AS group, than for the mild and moderate AS groups $(1.95 \pm 0.42$, $2.31 \pm 0.69,2.67 \pm 0.73 ; p<0.001$ respectively). In comparison of degenerative aortic stenosis groups with the control group, NLR in all aortic stenosis groups was found to be significantly higher than for the control group (Figure 1) $(p<0.001)$. In addition, there was a statistically significant correlation between NLR and transaortic peak pressure gradient in patients with degenerative aortic stenosis (Figure 2) ( $r: 0.626, p<0.001$ ).

Table 1. Demographic, echocardiographic and biochemical characteristics of study group patients

\begin{tabular}{|c|c|c|c|c|c|}
\hline & $\begin{array}{l}\text { Group } 1 \\
\text { Normal } \\
(n=35)\end{array}$ & $\begin{array}{l}\text { Group } 2 \\
\text { Mild } \\
(n=32)\end{array}$ & $\begin{array}{l}\text { Group } 3 \\
\text { Moderate } \\
(n=36)\end{array}$ & $\begin{array}{l}\text { Group } 4 \\
\text { Severe } \\
(n=35)\end{array}$ & $\mathbf{p}$ \\
\hline Age & $68.2 \pm 6.4$ & $69.9 \pm 5.8$ & $74.6 \pm 7.74$ & $72.2 \pm 9.29$ & 0.006 \\
\hline Female n (\%) & $16(24.2)$ & $18(27.3)$ & $20(30.3)$ & $12(18.2)$ & 0.22 \\
\hline $\mathrm{Hb}$ & $13.87 \pm 1.26$ & $13.75 \pm 1.03$ & $13.64 \pm 1.01$ & $13.60 \pm 1.39$ & 0.72 \\
\hline $\mathrm{Htc}$ & $41.75 \pm 3.38$ & $41.45 \pm 3.25$ & $41.77 \pm 3.16$ & $41.14 \pm 4.67$ & 0.88 \\
\hline Aorta Velocity m/sn & $1.84 \pm 0.42$ & $2.75 \pm 0.11$ & $3.4 \pm 0.22$ & $4.78 \pm 0.47$ & $<0.001$ \\
\hline Peak Gradient & $14.23 \pm 6.55$ & $30.44 \pm 2.62$ & $46.52 \pm 6.35$ & $92.25 \pm 19.2$ & $<0.001$ \\
\hline Mean Gradient & $4.155 \pm 1.639$ & $10.145 \pm 1.663$ & $20.572 \pm 3.719$ & $41.640 \pm 7.032$ & $<0.001$ \\
\hline LVEF \% & $63.11 \pm 2.87$ & $62.2 \pm 3.4$ & $64 \pm 3.55$ & $63.2 \pm 3.2$ & 0.148 \\
\hline IVS & $1.154 \pm 0.14$ & $1.222 \pm 0.17$ & $1.336 \pm 0.28$ & $1.497 \pm 0.21$ & $<0.001$ \\
\hline PW & $1.111 \pm 0.11$ & $1.168 \pm 0.16$ & $1.236 \pm 0.18$ & $1.340 \pm 0.15$ & $<0.001$ \\
\hline LV Mass & $192.990 \pm 39.7$ & $208.012 \pm 58.7$ & $232.902 \pm 74.5$ & $265.237 \pm 59.2$ & $<0.001$ \\
\hline NLR & $1.5 \pm 0.31$ & $1.95 \pm 0.42$ & $2.31 \pm 0.69$ & $2.67 \pm 0.73$ & $<0.001$ \\
\hline Creatinine & $0.8 \pm 0.16$ & $0.79 \pm 0.19$ & $0.9 \pm 0.16$ & $0.9 \pm 0.18$ & 0.007 \\
\hline HT & 20 & 12 & 19 & 19 & 0.38 \\
\hline DM & 20 & 13 & 14 & 15 & 0.40 \\
\hline HPL & 10 & 9 & 12 & 13 & 0.83 \\
\hline
\end{tabular}

HT, hypertension; DM, diabetes mellitus; HPL, hyperlipidemia; NLR, neutrophil/lymphocyte ratio; LVEF, left ventricle ejection fraction; $\mathrm{Hb}$, hemoglobin; Htc, hematocrit 


\section{DISCUSSION}

Degenerative aortic valve stenosis is an active disease process that represents proliferative and chronic inflammatory changes with lipid accumulation, up-regulation of angiotensin converting enzyme activity and infiltration of macrophages and $T$ lymphocytes. Macrophages and lymphocytes infiltrate into endothelium which release cytokines acting on valvular fibroblasts to promote cellular proliferation and extracellular matrix remodeling (7-9). Previous studies showed that degenerative aortic stenosis has similar pathophysiological and histological features with atherosclerotic coronary artery disease (10-12). But inflammation and its role in the presence and progression of aortic valve disease is controversial. In their study, Gunduz et al. showed that severity of aortic stenosis does not correlate with increasing CRP levels (13). In another study, Galanta et al. demonstrated that CRP levels increased in patients with degenerative aortic stenosis and also showed an independent association of CRP with aortic stenosis (14). Moreover, Sanches et al. reported that elevated CRP levels could be a marker of aortic stenosis progression (15).

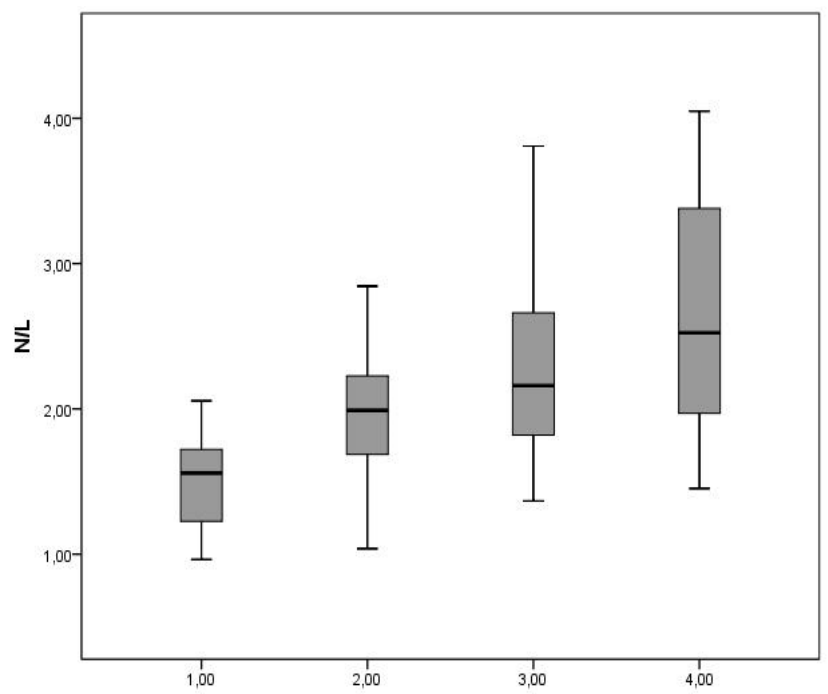

Figure 1. Box plot graph showing the neutrophil to lymphocyte ratios in control, mild, moderate, and severe aortic stenosis, respectively.

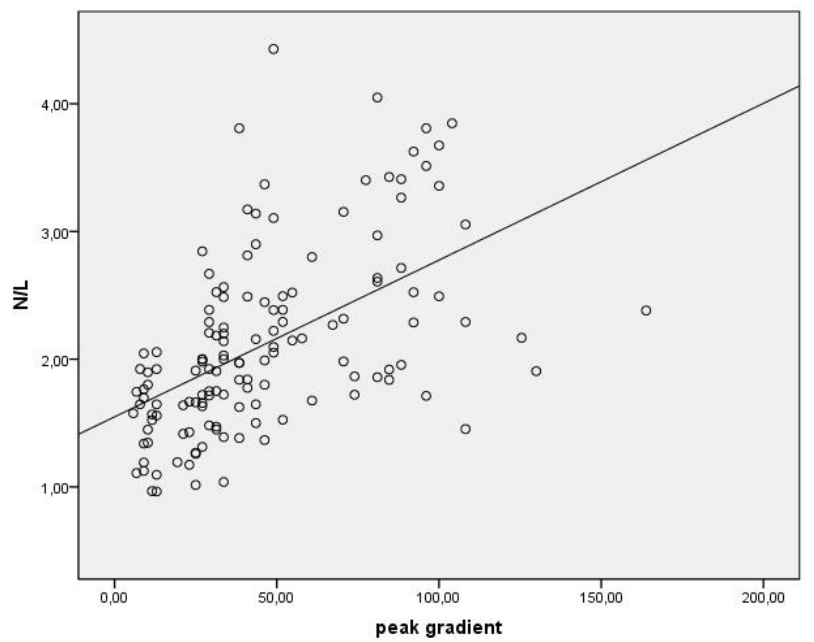

Figure 2. Correlation between NLR (neutrophil to lymphocyte ratio ) and transaortic peak pressure gradient

White blood cell count and its subtypes are known as classic markers of inflammation in cardiovascular disease. In previous studies, it has been shown that increased NLR levels are independent predictors of the severity of coronary artery disease and slow coronary flow phenomenon $(16,17)$. The relationship between NLR and atherosclerotic heart disease has been shown in several studies, yet there is limited available data about the association of NLR levels with degenerative AS. In our study, the NLR level was significantly higher in patients with AS compared to control group.
The NLR was positively correlated with transaortic peak pressure gradient and it was significantly higher in patients with severe AS, when compared to those with mild to moderate stenosis. Lymphocytes may have a critical role in modulating the inflammatory response in this chronic process.

Chronic pressure overload typically results in concentric left ventricle hypertrophy, with increased wall thickness and a normal chamber size in aortic stenosis. The increased wall thickness allows for normalization of wall stress, so that the left ventricle contractile function is maintained. Left ventricular overload with increased wall stress will result in remodeling process, which is predominantly governed by various inflammatory cascades. Pathophysiology of remodeling process includes increased pro-inflammatory cytokines expression, which is accompanied by leukocyte infiltration, and proteolytic myocardial destruction by neutrophil originated enzymes $(18,19)$. In their study, Avci et al. showed the highest NLR in patients with calcific severe aortic stenosis with depressed LV systolic function. Also similar to our study results, they found a positive correlation with transvalvular peak aortic gradient and the NLR (20). Although the rheumatic mitral valvular stenosis has a different pathophysiology which resembles an autoimmune-like process triggered by a streptococcal agent, they share a common result; increased myocardial (atrial and ventricle) wall stress and remodeling. In a recent study, Polat et al. showed that increased NLR was related to severity of rheumatic mitral stenosis and could be a useful inflammatory marker in patients with rheumatic valvular disease (21). The association of N/L ratio with the severity of mitral and aortic stenosis in previous studies can also be explained by the myocardial remodeling process. Also there are additional evidences regarding the $\mathrm{N} / \mathrm{L}$ ratio itself as a marker of ongoing inflammation and myocardial remodeling process $(21,22)$. Thus, rather than the chronic inflammation regarding the aortic valve itself, the increased left ventricular pressure overload caused left ventricular remodeling in chronic stage may be the explanation of our findings.

\section{CONCLUSION}

Increased NLR can be both a sign of ongoing inflammation and myocardial remodeling process in patients with degenerative aortic stenosis. However, these findings must be confirmed through a further study in which additional biomarkers of ventricular overload such as "brain natriuretic peptide" is used.

\section{Conflict of interest}

No conflict of interest was declared by the authors

\section{REFERENCES}

1.Dweck MR, Boon NA, Newby DE. Calcific aortic stenosis: A disease of the valve and the myocardium. J Am Coll Cardiol. 2012;60:1854-63.

2.Mazzone A, Epistolato MC, De Caterina R, Starti S, Vittorini S, Sbrana S, et al. Neoangiogenesis, T-lymphocyte infiltration, and heat shock protein- 60 are biological hallmarks of an immunomediated inflammatory process in end-stage calcified aortic valve stenosis. J Am Coll Cardiol. 2004, 43:1670-6.

3. Rajamannan NM, Gersh B, Bonow RO. Calcific aortic stenosis: from bench to the bedside - emerging clinical and cellular concepts. Heart. 2003, 89:801-5.

4.Freeman RV, Otto CM.Spectrum of calcific aortic valve disease: pathogenesis, disease progression, and treatment strategies. Circulation . 2005, 111:3316-6.

5.Bhat T, Teli S, Rijal J, Bhat H, Raza M, Khoueiry G, et al. Neutrophil to lymphocyte ratio and cardiovascular diseases: a review. Expert Rev Cardiovasc Ther. 2013;11:55-9.

6.Kaya MG. Inflammation and coronary artery disease: as a new biomarker neutrophil/lymphocyte ratio [in Turkish]. Turk Kardiyol Dern Ars. 2013;41 :191-92.

7.Losi MA, Brevetti G, Schiano V, Barbati G, Parisi V, Contaldi C, et al. Aortic valve sclerosis in patients with peripheral and/or coronary arterial disease. Echocardiography. 2010;27:608-12.

8.O'Brien KD, Reichenbach DD, Marcovina SM, Kuusisto J , Alpers CE, Otto $C M$, et al. Apolipoprotein $B,(a)$, and $E$ accumulate in the morphologically early lesion of degenerative valvular aortic stenosis. Arterioscler Thromb. $1996,16: 523-32$

9. Helske S, Lindstedt KA, Laine M, Mayranpaa M, Werkkala K, Lommi J, et al. Induction of local angiotensin II-producing systems in stenotic aortic valves. J Am Coll Cardiol. 2004;44:1859-66. 
10.Pohle K, Maffert R, Ropers D, Moshage W, Stilianakis N, Daniel WG ,et al. Progression of aortic valve calcification: association with coronary atherosclerosis and cardiovascular risk factors. Circulation. 2001;104:192732.

11.O'Brien KD. Pathogenesis of calcific aortic valve disease: a disease process comes of age (and a good deal more). Arterioscler Thromb Vasc Biol .2006;26:1721-8.

12.Otto CM, Kuusisto J, Reichenbach DD, Gown AM, O’Brien KD. Characterization nof the early lesion of 'degenerative' valvular aortic stenosis. Histological and immunohistochemical studies. Circulation.1994;90:844-53.

13.Gunduz H, Akdemir R, Binak E, Tamer A, Keser N , Uyan C, et al. Can serum lipid and CRP levels predict the "severity" of aortic valve stenosis? Acta Cardiol .2003, 58:321-6.

14.Galante A, Pietroiusti A, Vellini M, Piccola P, Possati G , De Bonis $M$,et al. $C$-reactive protein is increased in patients with degenerative aortic valvular stenosis. J Am Coll Cardiol. 2001, 38:1078-82.

15.Sanchez PL, Mazzone A. C-reactive protein in degenerative aortic valve stenosis. Cardiovasc Ultrasound. 2006, 4:24.

16. Kaya $H$, Ertas $F$, Islamoglu $Y$, Atılgan $Z A$, Çil $H$, Çalışkan $A$, et al. Association between neutrophil to lymphocyte ratio and severity of coronary artery disease. Clin Appl Thromb Hemost. 2014; 20 : 50-4
17.Dogan M, Akyel A, Cimen T, Bilgin M, Sunman H, Kasapkara HA, et al. Relationship between neutrophil to lymphocyte ratio and slow coronary flow. Clin Appl Thromb Hemost. $2015 ; 21$ : 251-4.

18. Heymans S, Hirsch E, Anker SD, Aukrust P, Balligand JL, Cohen-Tervaert $\mathrm{JW}$, et al. Inflammation as a therapeutic target in heart failure? A scientific statement from the Translational Research Committee of the Heart Failure Association of the European Society of Cardiology. Eur J Heart Fail. 2009;11:119-29

19.Uthamalingam S, Patvardhan EA, Subramanian S, Ahmed W, Martin W, Daley $M$,et al. Utility of the neutrophil to lymphocyte ratio in predicting long-term outcomes in acute decompensated heart failure. Am J Cardiol. 2011;107; 433-8

20.Avci A, Elnur A, Göksel A, Serdar F, Servet I ,Atilla K, et al. The Relationship between Neutrophil/Lymphocyte Ratio and Calcific Aortic Stenosis. Echocardiography. 2014; $31: 1031-5$

21.Polat N, Yildiz A, Yuksel M, Bilik MZ, Aydın M, Acet $H$, et al. Association of Neutrophil-Lymphocyte Ratio With the Presence and Severity of Rheumatic Mitral Valve Stenosis. Clin Appl Thromb Hemost. 2014; 20: 793-8

22. Sonmez O, Ertem FU, Vatankulu MA, Erdogan E, Tasal A, Kucukbuzcu S, et al. Novel fibro-inflammation markers in assessing left atrial remodeling in non-valvular atrial fibrillation. Med Sci Monit. 2014; 20: 463-70. 